\title{
$\mathrm{RF}$ 마그네트론 스퍼터링법으로 증착한 태양전지용 GZO/ITO 투명전도성 박막의 물성에 미치는 ITO층의 영향
}

\author{
정아로미, 송풍근 \\ 부산대학교 재료공학부
}

\section{Effect of ITO Layer on Electrical and Optical Properties of GZO/ITO Double-layered TCO Films Deposited by RF Magnetron Sputtering for Application to Solar Cells}

\author{
Ah-Ro-Mi Chung, Pung-keun Song* \\ Department of Materials Science and Engineering, Pusan National University, Busan, 609-735, Korea
}

(Received November 17, 2011 ; revised November 29, 2011 ; accepted December 30, 2011)

\begin{abstract}
GZO/ITO double layered films were deposited on unheated non-alkali glass substrates by RF magnetron sputtering using an ITO $\left(\mathrm{SnO}_{2}: 10 \mathrm{wt} \%\right)$ and $\mathrm{GZO}\left(\mathrm{Ga}_{2} \mathrm{O}_{3}: 5.57 \mathrm{wt} \%\right)$ ceramic targets, respectively. The electrical resistivity of GZO/ITO films depends on the thickness ratio between the GZO film and ITO film. With increasing ITO film thickness, the resistivity of GZO/ITO films decreased which due to large increase in the Hall mobility. Also, the crystallinity of GZO/ITO film was improved with an increase in ITO thickness which was evaluated by X-ray diffraction. The average transmittance of the films was more than $85 \%$ in the visible region, which is slightly higher than ITO single layer films.
\end{abstract}

Keywords: ITO, GZO, Magnetron sputtering, Double layer, Solar cells

\section{1. 서 론}

투명전도성 산화물(TCO, Transparent Conductive Oxide)은 높은 전기전도도와 가시광 영역에서의 우 수한 투과성을 나타내므로 LCD (Liquid crystal display), PDP (Plasma display panel), OLED (Organic light-emitting diode)등의 다양한 표시소자 및 TFT (Thin film transistor), 태양전지 패널의 투명전 극 재료로 널리 사용되고 있다 ${ }^{1,2)}$. 대표적인 투명전 도성 산화물로는 주석 $(\mathrm{Sn})$, 아연 $(\mathrm{Zn})$, 구리 $(\mathrm{Cu})$ 등을 치환 고용시킨 산화인듐 $\left(\operatorname{In}_{2} \mathrm{O}_{3}\right)$ 계와 알루미늄 $(\mathrm{Al})$, 갈륨 $(\mathrm{Ga})$, 인듐 $(\mathrm{In})$ 등을 치환 고용한 산화아연 $(\mathrm{ZnO})$ 계로 나눌 수 있으며 그 중 ITO (Indium tin oxide)

*Corresponding author. E-mail : pksong@pusan.ac.kr
는 약 $3.5 \mathrm{eV}$ 정도의 넓은 밴드갭을 가진 축퇴반도 체로서 전기적 및 광학적 특성이 우수하기 때문에 대표적 투명전도성 박막으로 가장 많이 사용되고 있다 ${ }^{3)}$. 하지만 $\mathrm{In}$ 의 경우, 공급불안에 따른 가격상 승 및 인체에 대한 유해성으로 인한 문제점이 지적 되고 있다. 따라서 보다 가격이 저렴하고 무독성의 친환경소재인 $\mathrm{ZnO}$ 계열의 $\mathrm{TCO}$ 물질이 $\mathrm{ITO}$ 를 대체 할 투명전극 재료로 각광받고 있다. $\mathrm{ZnO}$ 는 육방정 계 구조를 가지고 있으며 약 $3.3 \mathrm{eV}$ 정도의 밴드갭 에너지를 가진 축퇴 반도체로서 화학양론적 조성을 만족할 경우 낮은 전기전도성으로 인해 절연체에 가까운 성질을 나타내지만 ${ }^{4,5} \mathrm{Al}, \mathrm{Ga}$ 등과 같은 $\mathrm{III}$ 족 원소를 불순물로 첨가시키면 전기전도성이 향상 된다는 연구가 보고되고 있다 ${ }^{6,7)}$. GZO (Ga-doped zinc oxide)는 비저항이 $\sim 10^{-3} \Omega \mathrm{cm}$ 으로 ITO에 비해 
상대적으로 전기전도성은 나쁘지만 고온에서의 전 기적 특성의 안정성이 우수하기 때문에 태양전지용 투명전극으로서 응용이 기대된다. 따라서 본 연구 에서는 GZO 박막의 전기적 특성을 개선하기 위하 여 전기전도성이 뛰어난 ITO under layer를 도입하 였으며, 증착한 $\mathrm{GZO} / \mathrm{ITO}$ double layer의 전기적 및 광학적 물성에 대한 ITO층의 효과에 대해 조사하 였다.

\section{2. 실험방법}

기판으로는 $50 \mathrm{~mm} \times 50 \mathrm{~mm}$ 크기의 non-alkali 유 리(Corning E2000)를 사용하여 RF 마그네트론 스 퍼터링법(multi-sputtering system-b, DAEKI HITECH Co. Ltd.)으로 $\mathrm{ITO}$ 를 증착한 다음 그 위에 $\mathrm{GZO}$ 박 막을 증착하였다. 증착 전 챔버 내의 base pressure 는 약 $5 \times 10^{-6}$ Torr 이하까지 배기하였다. ITO 박막 은 $3 \mathrm{inch}$ 크기의 ITO $\left(\mathrm{SnO}_{2}: 10 \mathrm{wt} \%\right)$ 타겟을 사용 하였으며 증착압력은 약 $99.9995 \% \mathrm{Ar}$ 분위기에서 $0.25 \mathrm{~Pa}$ 을 유지하였다. 기판과 타겟 사이의 거리는 $50 \mathrm{~mm}, \mathrm{RF}$ 파워는 $70 \mathrm{~W}$ 로 유지하여 기판가열 없이 증착하였다. GZO 박막은 3 inch GZO $\left(\mathrm{Ga}_{2} \mathrm{O}_{3}: 5.57\right.$ $\mathrm{wt} \%)$ 타겟을 사용하여 $\mathrm{Ar}$ 분위기에서 스퍼터 압력 을 $1 \mathrm{~Pa}$ 로 유지하였고 타겟과 기판의 거리는 $30 \mathrm{~mm}$, $\mathrm{RF}$ 파워 $80 \mathrm{~W}$ 로 증착하였다. 증착조건은 각 타겟의 선행실험,9)을 통하여 최적의 조건을 정했으며 $\mathrm{GZO/}$ ITO 박막의 총 두께는 약 $400 \mathrm{~nm}$ 로 일정하게 유지 하면서 ITO층과 $\mathrm{GZO}$ 층의 두께비를 변화시켰다. ITO 박막의 두께를 $50 \mathrm{~nm}, 150 \mathrm{~nm}, 250 \mathrm{~nm}$ 로 변화시키 면서 위층에 증착되는 $\mathrm{GZO}$ 박막의 두께는 $350 \mathrm{~nm}$, $250 \mathrm{~nm}, 150 \mathrm{~nm}$ 로 증착하였다. $\mathrm{GZO}$ 층과 $\mathrm{ITO}$ 층의 두께비가 GZO/ITO double layer의 전기적 특성에 미치는 영향을 조사하기 위해 Hall effect measurements (HMS-3000, ECOPIA)를 사용하여 비저항, 캐 리어 농도, 홀 이동도를 측정하였다. 박막의 미세구 조는 X-ray diffraction (XRD, BRUKER GADDS) 으로 측정하였으며 표면형상은 atomic force microscope (AFM, XE-120, PSIA)를 이용하여 측정하였 다. 가시광 영역에서의 투과도는 $190 \mathrm{~nm}$ 에서 1100 $\mathrm{nm}$ 의 영역대에서 자외선 광학측정기 (UV-Vis, HP8453, AGILENT)를 사용하여 측정하였다.

\section{3. 결과 및 고찰}

그림 1은 GZO/ITO double layer에 있어서 ITO under layer의 두께 증가에 따른 전기적 특성(비저 항, 캐리어 농도, 홀 이동도)을 나타낸 것이다. GZO

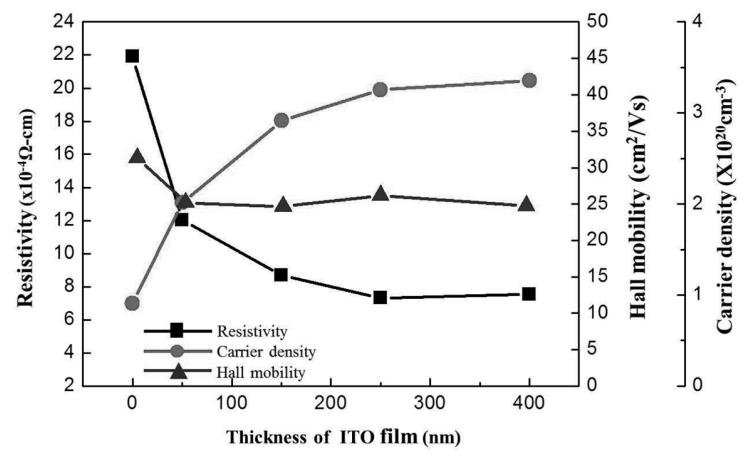

Fig. 1. Resistivity, carrier density and Hall mobility of GZO/ ITO films as a function of ITO thickness.

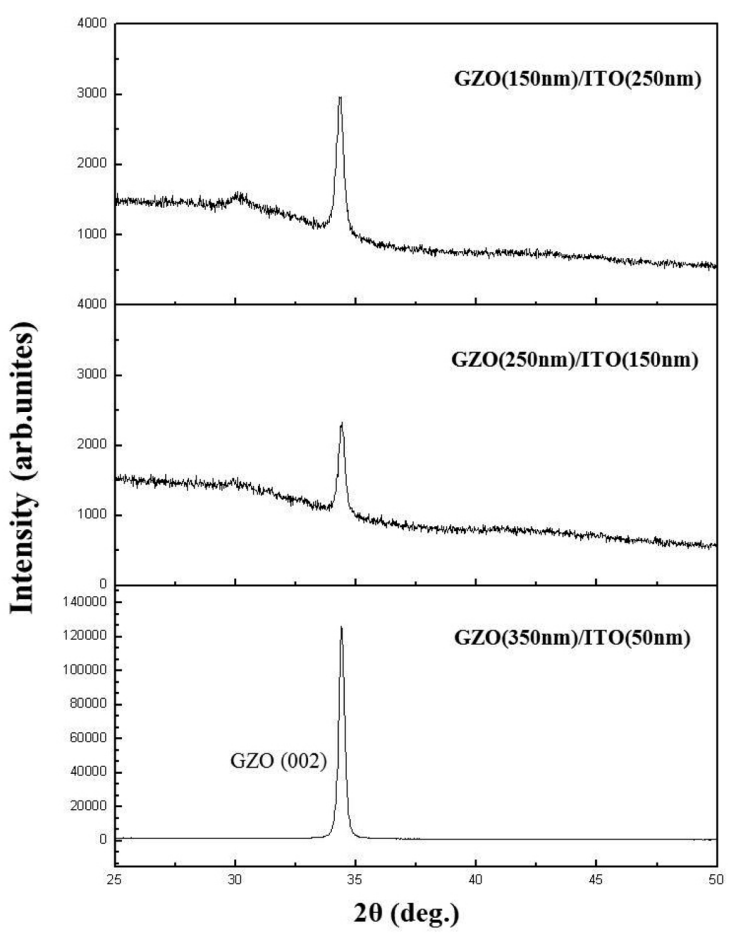

Fig. 2. X-ray diffraction patterns of GZO/ITO films with various ITO thicknesses.

단일박막과 ITO 단일박막의 두께는 $400 \mathrm{~nm}$ 로 일정 하게 유지하였으며, GZO/ITO 박막에서 ITO층의 두 께가 $50 \mathrm{~nm}, 150 \mathrm{~nm}, 250 \mathrm{~nm}$ 로 증가할수록 $\mathrm{GZO}$ 층 의 두께는 $350 \mathrm{~nm}, 250 \mathrm{~nm}, 150 \mathrm{~nm}$ 로 감소한다. 그 림 1 에서 볼 수 있듯이 $\mathrm{GZO} / \mathrm{ITO}$ 박막의 전기저항 은 ITO층의 두께가 증가할수록 감소하며 $\mathrm{GZO}$ 단 일박막에 비해 ITO층을 도입함으로써 비저항값이 감소한 것을 확인할 수 있었다. 또한 ITO층의 두께 가 증가할수록 $\mathrm{GZO/ITO} \mathrm{박막의} \mathrm{홀} \mathrm{이동도가} \mathrm{증가}$ 하는 경향을 볼 수 있으며 이는 GZO 단일박막의 홀 이동도에 비해 급격히 증가하였다. 하지만 ITO 층의 두께 증가에 따른 $\mathrm{GZO} / \mathrm{ITO}$ 박막의 캐리어 농 도 변화에서는 큰 차이를 나타내지 않았다. 따라서 


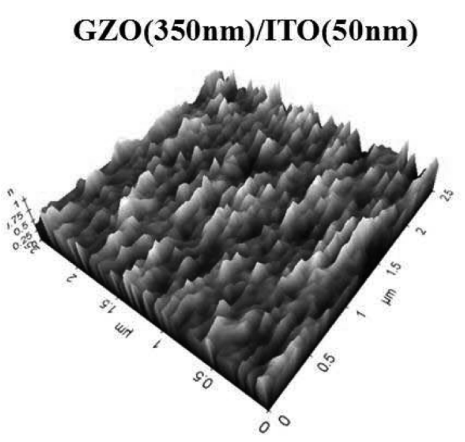

$R_{\mathrm{a}}: \mathbf{1 . 0 7 4 n m}$
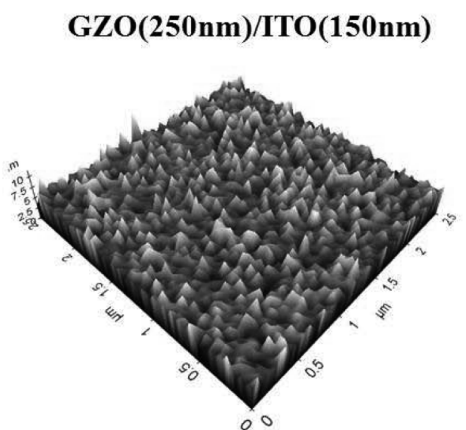

$R_{\mathrm{a}}: 1.087 \mathrm{~nm}$
GZO(150nm)/ITO(250nm)

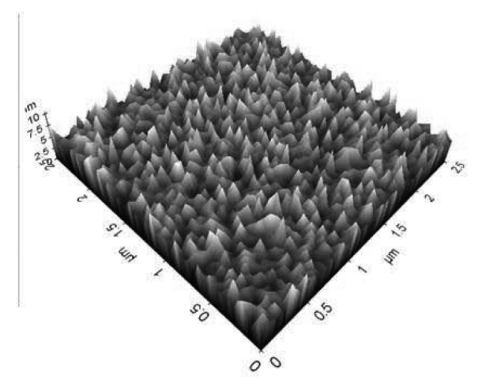

$R_{\mathrm{a}}: 1.112 \mathrm{~nm}$

Fig. 3. AFM images of GZO/ITO films deposited with various ITO thicknesses.

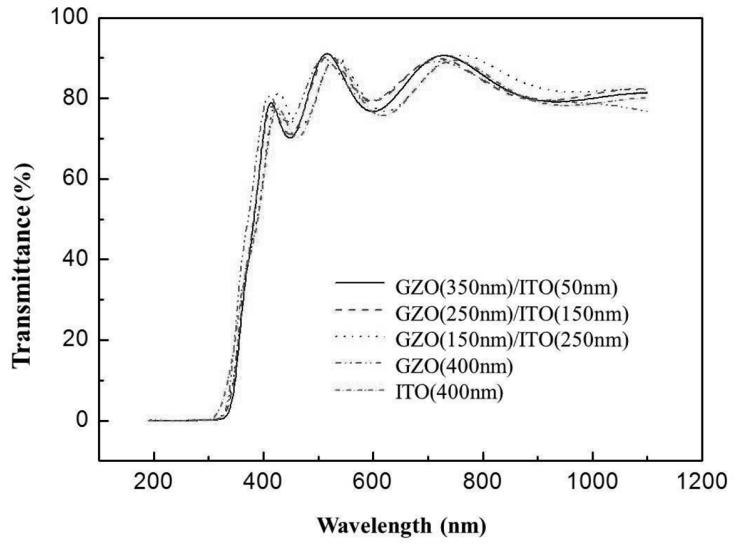

Fig. 4. Optical transmittance of GZO/ITO films, GZO film and ITO film.

$\mathrm{GZO} / \mathrm{ITO}$ 박막의 전기적 특성의 향상은 $\mathrm{ITO}$ 층의 도입에 따른 캐리어 농도 효과보다 홀 이동도의 증가 에 기인한 결과라 예상된다. 이것은 병렬저항법 ${ }^{10}$ 으로 설명되며 대부분의 캐리어 전자는 ITO층을 통 해 빨리 전송됨을 알 수 있다.

그림 2는 $\mathrm{ITO}$ 층의 두께 증가에 따른 $\mathrm{GZO} / \mathrm{ITO}$ 박막의 X-선 회절측정 결과를 나타낸 것이다. X-선 회절패턴의 결과 모든 $\mathrm{GZO/ITO} \mathrm{박막은} \mathrm{(002)면의}$ 우선배향을 하고 있음이 관찰되었다. 일반적으로 $\mathrm{GZO}$ 박막은 (002)면의 우선배향을 한다고 알려져 있으 며 c축 방향으로 주상구조를 가지고 성장한다 ${ }^{11)}$. 이 는 (002)방향의 면이 다른 방향의 면보다 표면의 자 유에너지가 낮아 육방정계구조를 갖는 GZO 박막 에서 우선적으로 성장했다고 생각된다. 실제로 $\mathrm{GZO}$ 의 표면 자유에너지의 값은 (002)면은 $0.0099 \mathrm{eV} / \mathrm{nm}$, (110)면은 $0.0123 \mathrm{eV} / \mathrm{nm},(101)$ 면은 $0.0209 \mathrm{eV} / \mathrm{nm}$ 값을 가진다. 따라서 (002)면이 결정 성장에 필요한 에너지 관점에서 보다 유리함을 알 수 있다 ${ }^{12,13)}$. 반 면 ITO 박막의 경우 X-선 회절패턴의 결과 피크가 나타나지 않고 hallow pattern이 관찰되었기 때문에 상온에서는 비정질구조를 가짐을 확인할 수 있었다.
따라서 GZO 박막의 두께 증가에 따른 (002)면의 피크 세기는 단조롭게 비례하여 증가함을 알 수 있 다. GZO/ITO 박막의 주 피크인 (002)면의 세기는 $\mathrm{GZO}(350 \mathrm{~nm}) / \mathrm{ITO}(50 \mathrm{~nm})$ 일 때 가장 큰 값을 나타 내는데 이것은 ITO층의 두께에 비해 상대적으로 $\mathrm{GZO}$ 층의 두께가 약 7배 두껍기 때문이다. GZO $(150 \mathrm{~nm}) / \mathrm{ITO}(250 \mathrm{~nm})$ 박막의 (002)면의 피크 세기 가 $\mathrm{GZO}(250 \mathrm{~nm}) / \mathrm{ITO}(150 \mathrm{~nm})$ 박막의 피크 세기보다 큰 값을 나타내는 것은 $\mathrm{GZO}$ 층의 절대적 두께차이 가 아니라 ITO under layer의 도입에 따라 ITO층 위에 성장하는 $\mathrm{GZO}$ 층의 미세구조가 달라졌을 것 이라 예상된다. $\mathrm{X}$ 선 회절측정 원리상 박막의 두께 가 두꺼울수록 주 성장면의 피크 세기는 커지는데 $\mathrm{GZO}(150 \mathrm{~nm}) / \mathrm{ITO}(250 \mathrm{~nm})$ 박막의 (002)면의 피크 세 기가 $\mathrm{GZO}(250 \mathrm{~nm}) / \mathrm{ITO}(150 \mathrm{~nm})$ 박막의 피크 세기값 보다 큰 것은 $\mathrm{ITO}$ 층의 두께가 증가함에 따라 상대적 으로 (002)면의 우선배향이 증가하였으며 또한 FWHM값이 작고 결정립의 크기가 커졌으므로 결정 성이 향상되었기 때문이다. 이는 $\mathrm{ITO}$ 층 위에 $\mathrm{GZO}$ 층 이 성장할 때, 빅스바이트(bixbyite) 구조인 $\mathrm{In}_{2} \mathrm{O}_{3}$ 와 $\mathrm{ZnO}$ 의 최밀충진면(closest-packed plane)의 인접산소 간에 $3 \%$ 미만의 격자불일치로 인해 near-epitaxial 성장을 하기 때문인 것으로 알려져 있다 ${ }^{14,15)}$. 따라 서 $\mathrm{GZO} / \mathrm{ITO}$ 박막의 홀 이동도 값이 증가하였으며 전기적 물성이 향상되었다.

그림 3은 $\mathrm{GZO}$ 층과 $\mathrm{ITO}$ 층의 두께비에 따라 증착 된 $\mathrm{GZO} / \mathrm{ITO}$ double layer의 표면형상에 대하여 $\mathrm{AFM}$ 을 이용하여 관찰한 결과이다. ITO under layer 의 두께가 증가함에 따라 박막 표면의 평균표면조 도 $\left(\mathrm{R}_{\mathrm{a}}\right)$ 값은 $1.074 \mathrm{~nm}$ 에서 $1.112 \mathrm{~nm}$ 로 증가하는 것을 확인할 수 있었다. 이것은 ITO층의 두께가 증가함 에 따라 $\mathrm{GZO}$ 층의 결정성장 시, 비정질기판의 영향 을 적게 받기 때문이다. 또한 ITO 박막의 결정립 크기 증가에 따른 GZO 박막의 결정성 향상에 기 인한 결과로 생각된다. 
그림 4는 non-alkali 유리기판 위에 증착된 $\mathrm{GZO} /$ ITO 박막의 투과율을 나타내었다. 모든 박막은 공 기를 기준으로 가시광 영역에서 약 $85 \%$ 이상의 투 과도를 나타내었으며 $\mathrm{GZO}$ 층의 두께가 증가할수록 (즉, ITO층의 두께가 감소할수록) 우수한 광투과율 을 보인다. 이것은 일반적으로 가시광 영역에서 ITO 와 비교하여 상대적으로 광 투과율이 높은 $\mathrm{GZO}$ 박 막의 두께 증가에 기인한다고 생각된다. 따라서 $\mathrm{GZO/ITO} \mathrm{박막의} \mathrm{평균} \mathrm{투과도는} \mathrm{ITO} \mathrm{단일박막보다}$ 높으며 그 수치는 GZO 단일박막의 가시광 영역에 서의 투과도만큼 개선되었음을 확인할 수 있었다.

\section{4. 결 론}

GZO upper layer와 ITO under layer의 두께비에 따라 GZO/ITO double layer를 RF 마그네트론 스퍼 터링법으로 non-alkali 유리기판 위에 기판가열 없이 증착하여 박막의 전기적 및 광학적 특성을 조사하 였다. ITO층의 두께가 증가함에 따라 $\mathrm{GZO/ITO} \mathrm{박}$ 막의 전기적 특성이 향상되는 것을 확인할 수 있었 다. 이는 ITO층의 도입에 따른 $\mathrm{GZO}$ 박막의 결정 성 향상에 기인한 것으로 $\mathrm{X}$-선 회절패턴 및 홀 이 동도 값의 증가와 일치하였다. 또한 박막의 평균표 면조도 $\left(\mathrm{R}_{\mathrm{a}}\right)$ 는 ITO층의 두께가 증가함에 따라 1.074 $\mathrm{nm}$ 에서 $1.112 \mathrm{~nm}$ 로 증가하는 것을 확인할 수 있었 으며 이는 $\mathrm{GZO/ITO}$ 박막의 최위층인 $\mathrm{GZO}$ 박막의 결정성 향상에 기인한 결과이다. 가시광 영역 $(550 \mathrm{~nm})$ 에서 $\mathrm{GZO} / \mathrm{ITO}$ 박막의 투과도는 $85 \%$ 이상으로 ITO 단일박막보다 우수한 투과율을 보이며 GZO 단일박 막의 투과도만큼 향상되었음을 확인할 수 있었다. $\mathrm{GZO} / \mathrm{ITO}$ 박막의 설계를 통해 ITO층을 도입함으로 써 GZO 박막의 전기적 물성을 개선하였으며 $\mathrm{GZO}$ 층을 증착함으로써 가시광 영역에서의 투과율 또한 향상되었다. 이를 통해 태양전지 패널 전극용 투명 전도성 박막으로의 활용이 기대된다.

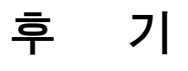

This research was supported in part by $R \& D$ project of MKE/KEIT [10039263, Development of window-unified 30" touch sensor].

\section{참고문헌}

1. Y. H. Jung, E. S. Lee, K. H. Kim, J. Kor. Inst. Surf. Eng. 38 (2005) 150.

2. Z. C. Jin, I. Harmberg, C. G. Granqvist, Thin Solid Films, 64 (1988) 381.

3. J. W. Moon, D. W. Kim, J. Kor. Inst. Surf. Eng. 40 (2007) 117.

4. D. R. Sahu, J.-L. Huang, Microelectron. J. 38 (2007) 299.

5. Y. S. Park, S. H. Lee, P. K. Song, J. Kor. Inst. Surf. Eng. 40 (2007) 107.

6. S. J. Henley, M. N. R. Ashfold, D. Cherns, Surf. Coat. Technol. 177-178 (2004) 271.

7. C. S. Hong, H. H. Park, J. Moon, H. H. Park, Thin Solid Films, 515(3) (2006) 957.

8. S. I. Kim, T. D. Jung, P. K. Song, Thin Solid Films, 518 (2010) 3085.

9. S. H. Park, J. B. Park, P. K. Song, Current Applied Physics, 10 (2010) S488.

10. S. Y. Ryu, Applied Physics Letters, 92 (2008) 023306.

11. X. W. Sun, L. D. Wang, H. S. Kwok, Thin Solid Films, 360 (2000) 75.

12. N. Fujimura, T. Nishihara, S. Goto, J. Xu, T. Ito, J. Crystal Growth, 130 (1993) 269.

13. S. E. Park, S. H. Park, J. Lue, P. K. Song, J. Kor. Inst. Surf. Eng. 41 (2008) 142.

14. C. H. Yi, I. Yasui, Y. Shigesato, Jpn. J. Appl. Phys. 34 (1995) 1639.

15. R. Vinodkumar, K. J. Lethy, D. Beena, A. P. Detty, I. Navasa, U. V. Nayar, V. P. MahadevanPillai, V. Ganesan, V. R. Reddy, Solar Energy Materials \& Solar Cells, 94 (2010) 68. 